\title{
Transfer of Sulfamethazine from Contaminated Beeswax to Honey
}

\author{
Wim Reybroeck, ${ }^{*}{ }^{\dagger}$ Frans J. Jacobs, ${ }^{\star}$ Hubert F. De Brabander,${ }^{\S}$ and \\ Els DAeseleire ${ }^{\dagger}$ \\ ${ }^{\dagger}$ Institute for Agricultural and Fisheries Research (ILVO), Technology and Food Science Unit, \\ Brusselsesteenweg 370, 9090 Melle, Belgium, 'Department of Biochemistry, Physiology and Microbiology, \\ Laboratory for Zoophysiology, Ghent University, Krijgslaan 281 (S33), B-9000 Gent, Belgium, and \\ ${ }^{\S}$ Faculty of Veterinary Medicine, Laboratory of Chemical Analysis, Ghent University, Salisburylaan 133,
} 9820 Merelbeke, Belgium

\begin{abstract}
A liquid chromatographic tandem mass spectrometric method for the determination of sulfa drugs in beeswax was developed. When performing residue control on beeswax intended for the fabrication of wax foundations, residues of sulfonamides were found. A migration test was set up to study whether sulfonamide-containing beeswax could lead to the contamination of honey. The higher the concentration of sulfamethazine doped in the wax, the higher was the concentration of sulfamethazine found in the honey. The maximum transfer was 15.6, 56.9, and $29.5 \%$ of the initial amount spiked in the wax foundation. In a second experiment, the percentage of sulfamethazine migrating from medicated winter feed to beeswax in relation to the concentration in the syrup and the contact time was studied. The maximum transfer of sulfamethazine from medicated sucrose syrup to beeswax was $3.1 \%$.
\end{abstract}

KEYWORDS: Honey; sulfonamides; beeswax; honeybees; residues; migration

\section{INTRODUCTION}

The use of sulfonamides to protect honey bees against bacterial diseases became a common practice in commercial beekeeping after Haseman and Childers (1) learned that sulfa drugs, particularly sulfathiazole, could prevent the spread of American foulbrood (AFB). The compound sulfathiazole provided a short-term control by suppressing the symptoms of the bee disease caused by Paenibacillus larvae. It also prevented the reproductive spores from germinating. The use of sulfa drugs in the bees' food in the spring and fall was also encouraged by other authors $(2-6)$. Despite the effectiveness of sulfonamides against AFB, their stability and consequent residues in honey caused problems, and the registration was allowed to lapse in the 1970s (7).

Another important bee pathogen is Nosema apis, which causes nosemosis, the most widespread of all adult honey bee diseases. Until recently, Nosema apis had been considered to be a microsporidian, a single-celled protozoan, but is now classified as a fungus or as fungi-related (8). Recently, Nosema ceranae showed to be widespread in some European regions, afflicting the adult bees and resulting in depopulation and bee colony losses (9). The effectiveness of fumagillin, an antibiotic prepared from Aspergillus flavus, was found to be effective in 1952 by Katznelson and Jamieson (10). It is commonly used in beekeeping to prevent and control Nosema disease in several parts of the world. In the EU, fumagillin is no longer available (11). Some publications or

*Corresponding author. Tel: +32927230 11. Fax: +3292723001. E-mail: wim.reybroeck@ilvo.vlaanderen.be. manuals mention that sulfa drugs can be used against nosemosis $(12,13)$ or to treat infections due to microsporidia $(14-16)$.

Sulfonamides play an important role as effective chemotherapeutics for bacterial and protozoal diseases in veterinary medicine. They are frequently administered in combination with dihydrofolate reductase inhibitors of the group of diaminopyrimidines (17). In Europe, sulfonamides were classified in Annex I of Regulation (EEC) 2377/90 with a maximum residue limit (MRL) fixed at $100 \mu \mathrm{g} \mathrm{kg}^{-1}$ for the combined residues of all compounds in the sulfonamide group in meat, fat, liver, and kidney from all food-producing species (since 1992) and in bovine, ovine, and caprine milk (since 1994) (18). In the current legislation, they are classified as allowed substances with the same MRLs $(19,20)$. However, no MRLs are set for sulfonamides in honey. As a consequence, a zero tolerance policy regarding residues of sulfonamides in honey is applied. Some EU member states established action limits (e.g., Belgium at $20 \mu \mathrm{g} \mathrm{kg}^{-1}$ ) (21), reporting limits (e.g., U.K. at $50 \mu \mathrm{g} \mathrm{kg}^{-1}$ ) (22), or tolerance levels (e.g., Switzerland at $50 \mu \mathrm{g} \mathrm{kg}^{-1}$ ) (23) for sulfa drugs. This takes analytical possibilities and available toxicological data into account in order to facilitate international trade. The European community reference laboratory proposed $50 \mu \mathrm{g} \mathrm{kg}^{-1}$ as the recommended concentration for the screening of sulfonamides in honey (24). Despite the lack of MRLs for sulfonamides in honey, sulfa drugs could be used in the EU in apiculture based on the cascade system as described in article 11 of Directive 2001/82/ EC (25), as amended by Directive 2004/28/EC (26). The cascade system was introduced to solve the general problem of availability 
of veterinary medicinal products for minor species. The cascade system is open to all animal species, including honeybees, provided that the active substance concerned has been included in Annex I, II, or III of Regulation (EEC) 2377/90 and the prescribing veterinarian specifies a withdrawal period (27).

In the framework of a quality program, locally produced honey has been examined at ILVO for the presence of residues of antimicrobials since the year 2000. In the period 2000-2001, 4 out of 248 samples contained streptomycins, 2 out of 72 samples were positive for tetracyclines, and 3 out of 72 samples had sulfa drug residues. For the streptomycin and tetracycline contamination, most cases involved the beekeeper admitting to having added foreign honey to his production (28). In 2002, sulfa drugs were found in 3 out of 91 samples. In 2003, 12 out of 203 samples contained residues of sulfonamides. In most cases, it concerned sulfamethazine (up to $13000 \mu \mathrm{g} \mathrm{kg} \mathrm{kg}^{-1}$ ), and in one case, a combination of sulfamethazine $\left(458 \mu \mathrm{g} \mathrm{kg}^{-1}\right)$ and sulfathiazole (1229 $\mu \mathrm{g} \mathrm{kg}^{-1}$ ) was found (29). Since 2004, no antimicrobial residues were found in locally produced honey examined for the presence of (dihydro)streptomycin, tetracyclines, sulfonamides, chloramphenicol, macrolides (since 2006), lincosamides (since 2006), and fluoroquinolones (since 2006). This testing occurred in the framework of the Flemish honey quality program (30 and unpublished data). Questioning of the beekeeper proved that the high concentrations found in 2002 and 2003 were caused by the use of sulfonamides to prevent or to treat nosemosis. However, in five honey samples, the contamination of sulfonamides was limited to concentrations below $50 \mu \mathrm{g} \mathrm{kg}^{-1}$. The five producers involved all claimed not to have used preparations containing sulfonamides. External sources of contamination thus needed to be considered. Other authors reported about the presence of residues of sulfonamides in honey $(23,31-36)$. In 2008 in Europe, there were 9 notifications in the Rapid Alert System for Food and Feed (RASFF) from the Directorate-General for Health \& Consumers about residues of sulfonamides in honey (37). It concerned sulfathiazole in honey from Hungary, Lithuania (2 notifications), and Portugal, sulfamethazine in honey from Turkey (3 notifications) and Egypt, and sulfadiazine in honey from China. In 2009, there was only 1 notification regarding sulfamethazine in honey from Turkey.

At ILVO, screening of honey samples on the presence of residues of sulfa drugs is performed by Charm II Sulfonamides Honey (Charm Sciences Inc., Lawrence, MA). Confirmation of suspect samples is performed by a liquid chromatographictandem mass spectrometric method validated according to Commission Decision 2002/657 (38) for seven sulfonamides (sulfapyridine, sulfadiazine, sulfamethoxazole, sulfathiazole, sulfamerazine, sulfamethazine, and sulfaquinoxaline), using sulfachloropyridazine as internal standard.

Besides honey, beeswax is also an important bee product. Beeswax is a natural wax produced by the worker bees in their wax-producing mirror glands on the inner sides of the sternites on abdominal segments 4 to 7 . The new wax scales are masticated by the worker bees and used to build honeycomb cells in which their young are raised and honey and pollen are stored. Ripened honey is also capped with wax. Beeswax is an extremely complex material that contains over 300 different substances. Its main components are palmitate, palmitoleic acid, hydroxypalmitate, and oleate esters of long-chain aliphatic alcohols. Beeswax has a high melting point, ranging from 61 to $65^{\circ} \mathrm{C}(39)$. Beeswax is often contaminated with residues of pesticides and acaricides that then contaminate the honey $(40,41)$. A liquid chromatographictandem mass spectrometric (LC-MS/MS) method was developed for the determination of sulfonamides in beeswax. When performing residue control on 10 samples of beeswax intended for the fabrication of wax foundations, residues of sulfonamides were found in imported beeswax as well as in local beeswax. Crude beeswax from India contained $325 \mu \mathrm{g} \mathrm{kg}$-1 sulfadiazine, while crude Belgian beeswax from hives treated with sulfonamides was contaminated with $62 \mu \mathrm{g} \mathrm{kg}^{-1}$ sulfadiazine. In wax from a honeycomb from a Flemish apiary producing honey contaminated with sulfonamides, $14 \mu \mathrm{g} \mathrm{kg}^{-1}$ sulfamethazine was found (29). To our knowledge, no studies were performed in the past to check if sulfa-containing beeswax could lead to contamination of the honey. We set up a migration test to investigate this possibility.

A second experiment determined the residue concentration build up in beeswax after different contact times with sulfamedicated syrup.

\section{MATERIALS AND METHODS}

Reagents and standards. Sulfapyridine (S-6252), sulfadiazine (S-8626), sulfamethoxazole (S-7507), sulfathiazole (S-0127), sulfamerazine (S-9001), sulfamethazine (S-6256), sulfaquinoxaline (S-7382), and sulfachloropyridazine (S-9882, internal standard) all came from Sigma-Aldrich (Bornem, Belgium). Individual standard stock solutions were prepared by weighing approximately $5 \mathrm{mg}$ of standard in a glass tube and adding an appropriate amount of acetonitrile/water $(50: 50, \mathrm{v} / \mathrm{v})$ to reach a concentration of $1 \mathrm{mg} \mathrm{mL}{ }^{-1}$. Stock solutions were stored at $-18{ }^{\circ} \mathrm{C}$. Working solution 1 , containing the seven sulfa drugs at $10 \mu \mathrm{g} \mathrm{mL}^{-1}$, was prepared daily by diluting the stock solutions in a mixture of acetonitrile-water $(50: 50, \mathrm{v} / \mathrm{v})$. The composite working solution 2 of $1 \mu \mathrm{g} \mathrm{mL}^{-1}$ was prepared by diluting working solution 1 in water.

$n$-Hexane (082906), acetonitrile (012078), methanol (136878), and formic acid (069178) came from Biosolve (Valkenswaard, The Netherlands). Sodium acetate (62648), sodium sulfate (106647), and acetic acid (1.00063) were from Merck KGaA (Darmstadt, Germany). Hydrochloric acid (2 M) (403872) came from Carlo Erba (Milan, Italy). Sodium hydroxide (B405348019) came from BDH Laboratory Supplies (Poole, United Kingdom). The MSU extraction buffer came from Charm Sciences Inc. (Lawrence, MA). Water was HPLC grade (generated by an ELGA purification system). Filters (Millex GV, $0.22 \mu \mathrm{m}, \mathrm{SLGVX13)}$ ) for filtration of the extract were from Millipore (Billerica, MA). Solid phase extraction columns were Sep-Pak tC18 columns (500 mg, $6 \mathrm{~mL}$, WAT036790) from Waters (Millford, MA). Syrup was prepared from ultra grade sucrose (S7903) from Sigma-Aldrich (Bornem, Belgium). A syrup concentration of $67 \% \mathrm{w} / \mathrm{v}$ ( $2: 1$ sucrose/water by weight) was used. The blank beeswax, obtained from a Flemish hobby beekeeper, had no evidence of any sulfa drug residue as tested by LC-MS/MS analysis. The Petri plastic dishes of $14 \mathrm{~cm}$ diameter were from Plastiques-Gosselin (Hazebrouck, France).

Apparatus. The LC-MS/MS system for the honey and beeswax analyses consisted of an Alliance Separations Module 2695 system from Waters (Millford, MA) coupled to Quattro LC (triple quadrupole) of Micromass (Manchester, United Kingdom) equipped with the Z-spray system. The MS system was controlled by version 3.3 of the MassLynx software (Waters, Millford, MA). Chromatography for honey and beeswax analysis was performed on a XTerra MS C 18 column (186000546, Waters, Millford, MA). The column (particle size $5 \mu \mathrm{m}, 150 \mathrm{~mm} \times 2.1 \mathrm{~mm}$ i.d.) was protected by a guard column containing the same material.

The following small lab equipments were used: a shaking device KS250 from IKA Werke GmbH \& Co.KG (Staufen, Germany), a centrifuge Centra-CL3 from Thermo IEC (Needham Heights, MA), an incubator BD240 with natural convection from Binder GmbH (Tittlingen, Germany), a water bath and heating circulator from Julabo Labortechnik GmbH (Seelbach, Germany), and an ultrasonic bath Branson 2200 Ultrasonic Cleaner from Branson Ultrasonics Corporation (Danbury, CT).

Sample Preparation. For honey, the cleanup was based on the method described by Maudens et al. (44). Honey was homogenized by manual stirring. An aliquot of $1.5 \mathrm{~g}$ of the homogenized honey sample was weighed in a centrifuge tube of $50 \mathrm{~mL}$. At this stage, $50 \mu \mathrm{g} / \mathrm{kg}$ of sulfachloropyridazine (Internal Standard) was added, and the sample was allowed to stand for $20 \mathrm{~min}$. After the addition of $1.5 \mathrm{~mL}$ of a $2 \mathrm{M} \mathrm{HCl}$ solution, we placed the tube in a shaking device for $30 \mathrm{~min}$. After 
adjustment of the $\mathrm{pH}$ to 5.0 with $550 \mu \mathrm{L}$ of $5 \mathrm{M} \mathrm{NaOH}$ and $750 \mu \mathrm{L}$ of $1.2 \mathrm{M}$ sodium acetate, we added $8 \mathrm{~mL}$ of acetonitrile and placed the tube again on the shaking device for $30 \mathrm{~min}$. After centrifugation for $30 \mathrm{~min}$ at 1800 RCF, we decanted the upper layer into a second centrifuge tube and added $5 \mathrm{~g}$ of sodium acetate. After shaking during $5 \mathrm{~min}$, we centrifuged the tube for $10 \mathrm{~min}$ at $1800 \mathrm{RCF}$ and transferred the liquid layer to a glass tube. The extract was evaporated under nitrogen in a water bath of $45^{\circ} \mathrm{C}$. The residue was dissolved in $2 \mathrm{~mL}$ of a $1 \%$ acetic acid solution, and the tube was placed for $5 \mathrm{~min}$ in an ultrasonic bath. Solid phase extraction columns $\left(\mathrm{SPE} \mathrm{C}_{18}\right)$ were conditioned with $5 \mathrm{~mL}$ of methanol and $2 \times 5 \mathrm{~mL}$ of water. The honey extract was brought onto the column and was allowed to flow through the column at a slow flow rate. The column was washed with $5 \mathrm{~mL}$ of water, and after drying, we eluted the sulfonamides from the column with $1.3 \mathrm{~mL}$ of methanol. The extract was evaporated under nitrogen in a water bath of $45^{\circ} \mathrm{C}$. The extract was dissolved in $500 \mu \mathrm{L}$ of the mixture of acetonitrile/water $(50: 50, \mathrm{v} / \mathrm{v})$ and $0.1 \%$ formic acid, and after filtration, we brought the extract into a HPLC vial and injected $40 \mu \mathrm{L}$ into the LC-MS/MS system. With each series of samples, a blank sample, samples spiked at 2, 5, 10,20,50, and $100 \mu \mathrm{g} \mathrm{kg}^{-1}$ sulfamethazine (calibration curve), and a second line control sample (spiked by the laboratory responsible or by another technician) were analyzed.

Beeswax Preparation. Five grams of beeswax, cut into small pieces, was weighed in a centrifuge tube of $50 \mathrm{~mL}$. After the addition of $200 \mu \mathrm{g} \mathrm{kg}^{-1}$ sulfachloropyridazine as internal standard, we dissolved the beeswax in $30 \mathrm{~mL}$ of hexane by shaking on a shaking device at $500 \mathrm{rpm}$. Afterward, $20 \mathrm{~mL}$ of MSU extraction buffer was added. The tube was manually shaken for $2 \mathrm{~min}$, sonicated for $5 \mathrm{~min}$ in an ultrasonic bath, and again manually shaken for $2 \mathrm{~min}$. After centrifugation for $10 \mathrm{~min}$ at $2850 \mathrm{RCF}$, we discarded the supernatant and transferred the water phase to another centrifuge tube of $50 \mathrm{~mL}$. The solid phase extraction column $\left(\mathrm{SPEC}_{18}\right)$ was conditioned with $5 \mathrm{~mL}$ of methanol and $2 \times 5 \mathrm{~mL}$ of HPLC water. The extract was allowed to flow through the column at a slow flow rate. The column was washed with $5 \mathrm{~mL}$ of water, and after drying, we eluted the sulfonamides from the column with $2.5 \mathrm{~mL}$ of methanol. The methanol was evaporated under nitrogen at $45^{\circ} \mathrm{C}$, and the residues were dissolved in $500 \mu \mathrm{L}$ of acetonitrile/water $(50: 50, \mathrm{v} / \mathrm{v})$ containing $0.1 \%$ formic acid, and after filtration, we brought the extract into a HPLC vial and injected $40 \mu \mathrm{L}$ into the LC-MS/MS system. With each series of samples, a blank sample, samples spiked at 100, 200,500, 750, and $1000 \mu \mathrm{g} \mathrm{kg}^{-1}$ sulfamethazine (calibration curve), and a second line control sample were analyzed.

LC-MS/MS Analyses. The LC separation was performed on a reversed-phase column with an organic mobile phase. The mobile phase consisted of water (A) and acetonitrile (B), both containing $0.1 \%$ formic acid. The gradient conditions were as follows: from 0 to $0.5 \mathrm{~min}$, held $100 \% \mathrm{~A}$; ramped over $0.1 \mathrm{~min}$ to $55 \% \mathrm{~A}$ and $45 \% \mathrm{~B}$; ramped over $7.9 \mathrm{~min}$ to $35 \% \mathrm{~A}$ and $65 \% \mathrm{~B}$; ramped over $0.1 \mathrm{~min}$ to $100 \% \mathrm{~B}$; held for $10 \mathrm{~min}$; ramped over $1.4 \mathrm{~min}$ to $100 \% \mathrm{~A}$; held $100 \%$ A for 10 min to reequilibrate the system. The flow rate was $0.25 \mathrm{~mL} / \mathrm{min}$. The abundant parent ions $[\mathrm{M}+\mathrm{H}]^{+}$produced by positive electrospray ionization were selected for collisional dissociation with argon. When analyzing honey or beeswax from unknown origin, for each of the 7 sulfa drugs the transition of the precursor ion into at least two product ions was followed in multiple reaction monitoring in order to obtain enough identification points, as required in Commission Decision 2002/657/EC (38). All compounds could be detected in one run. A summary of the cone voltages, collision energies, precursor and product ions, and retention times of the 7 compounds is presented in Table 1.

The Quattro LCZ mass spectrometer was operated in ESI-MS/MS positive ion mode. High-purity nitrogen was used as drying gas and as ESI nebulizing gas. Argon was used as collision gas to obtain product ions. Dwell time and interchannel delay were optimized with standard solutions and were set at 0.5 and 0.03 , respectively. The source block and desolvation temperature were set at 120 and $300{ }^{\circ} \mathrm{C}$, respectively.

Calculation of Partition Coefficients. The partition coefficient of some sulfonamides was calculated using Advanced Chemistry Development (ACD/Laboratories) Software, version 8.14 (1994-2010 ACD/ Laboratories, Toronto, Canada).

Experiments and Sampling. In a first experiment, we placed sulfamethazine-containing wax foundations in beehives in order to see whether this practice could lead to contamination of the produced honey. A wax foundation is a thin sheet of beeswax that is embossed with the hexagonal
Table 1. Summary of Tuning and Chromatographic Parameters for Honey Analysis

\begin{tabular}{|c|c|c|c|c|c|}
\hline compound & $\begin{array}{l}\text { precursor } \\
\text { ion }(\mathrm{m} / \mathrm{z})\end{array}$ & $\begin{array}{c}\text { cone } \\
\text { voltage (V) }\end{array}$ & $\begin{array}{c}\text { product } \\
\text { ions }(\mathrm{m} / \mathrm{z})\end{array}$ & $\begin{array}{c}\text { collision } \\
\text { energy }(\mathrm{eV})\end{array}$ & $\begin{array}{l}\text { retention } \\
\text { time (min) }\end{array}$ \\
\hline \multirow[t]{3}{*}{ sulfamethazine } & 279.06 & 35 & 155.94 & 20 & 7.57 \\
\hline & & & $91.99^{a}$ & 30 & \\
\hline & & & 124.15 & 27 & \\
\hline \multirow[t]{3}{*}{ sulfapyridine } & 250.00 & 30 & $156.00^{a}$ & 15 & 7.35 \\
\hline & & & 92.10 & 28 & \\
\hline & & & 108.00 & 25 & \\
\hline \multirow[t]{3}{*}{ sulfadiazine } & 250.94 & 27 & $156.06^{a}$ & 16 & 7.35 \\
\hline & & & 92.18 & 25 & \\
\hline & & & 107.95 & 22 & \\
\hline \multirow[t]{3}{*}{ sulfamethoxazole } & 253.97 & 24 & 156.10 & 15 & 8.21 \\
\hline & & & $91.99^{a}$ & 25 & \\
\hline & & & 108.07 & 25 & \\
\hline \multirow[t]{3}{*}{ sulfathiazole } & 256.07 & 26 & 156.19 & 15 & 7.28 \\
\hline & & & $92.11^{a}$ & 27 & \\
\hline & & & 107.95 & 25 & \\
\hline \multirow[t]{3}{*}{ sulfamerazine } & 265.10 & 25 & $156.04^{a}$ & 17 & 7.50 \\
\hline & & & 92.01 & 28 & \\
\hline & & & 108.00 & 25 & \\
\hline \multirow[t]{3}{*}{ sulfaquinoxaline } & 301.07 & 25 & $156.18^{a}$ & 17 & 8.49 \\
\hline & & & 92.00 & 30 & \\
\hline & & & 108.04 & 28 & \\
\hline sulfachloropyridazine & 285.02 & 27 & 156.00 & 15 & 7.99 \\
\hline
\end{tabular}

${ }^{a}$ Most abundant product ion.

shape that the bees naturally form for their honeycomb. The bees draw out the comb by adding wax on top of the foundation to create hexagonal cells, where the honey and pollen are stored, and the eggs are laid by the queen. In general, beekeepers buy the wax foundations at a beekeepers' shop. The wax foundations for the experiment were made by molding wax by means of negative silicone templates of a beeswax sheet, pouring hot wax of $80^{\circ} \mathrm{C}$ into it and closing the mold and allowing the wax to cool. To prepare sulfamethazine-containing wax foundations, liquid blank beeswax was spiked with sulfamethazine at three different levels, namely, 1, 10, and $100 \mathrm{~m} \mathrm{~kg}^{-1}$. Sulfamethazine was dissolved in $5 \mathrm{~mL}$ of methanol, added to $120 \mathrm{~g}$ of liquid beeswax, and mixed by hand with a stainless steel stirrer. After molding, a small amount of each wax foundation was sampled for sulfamethazine residue analysis by LC-MS/MS. The spiked wax foundations were placed in rectangular wooden frames with wires across the vertical center to hold the wax foundations in place. In mid-June, the start of the summer blossoming season, each frame with a spiked wax foundation was placed close to the brood nest in a different hive of the experimental apiary of UGent, to let the honeybees (Apis mellifera L.) draw out the spiked wax foundation to honeycomb. The three free-flying colonies were housed in double brood boxes with 11 Simplex standard frames $(34.0 \mathrm{~cm}$ by $19.6 \mathrm{~cm}$ of comb; $2.3 \mathrm{~cm}$ thickness of the wooden frame) and one super box. After 1 week, the frames were transferred to the super box of the hives to prevent the queen from laying eggs in the combs. The supers were separated from the rest of the hives by a queen excluder. At four weeks from the start, the combs contained capped honey, and the frames were removed from the hives for a first sampling of honey. The honeycombs were further incubated for 3 months in the laboratory in an incubator with natural convection at $35^{\circ} \mathrm{C}$, corresponding to the temperature in the hive, and sampled monthly. The sampling of honey was performed by spooning from both sides of the comb. In the sampled honey, the quantity of sulfamethazine was determined by LC-MS/MS. Honey was also sampled from other frames present in the supers of the hives participating in the trial. These control samples were analyzed on the presence of residues of sulfonamides. Before analysis, honey and wax were separated by sieving at a temperature of $30-35^{\circ} \mathrm{C}$ to prevent interference by small wax particles present in the honey.

A second experiment investigated the possible level of contamination of beeswax caused by transfer from medicated syrup solution. Large Petri dishes were filled with $30 \mathrm{~mL}$ (= $29 \mathrm{~g}$ ) of blank beeswax. Winter feed solution of $67 \% \mathrm{w} / \mathrm{v}$ sucrose was prepared and spiked with sulfamethazine at three different concentrations, namely, 30, 150, and $750 \mathrm{mg} \mathrm{L}^{-1}$. In each Petri dish, $50 \mathrm{~mL}$ of medicated syrup was poured on top of the $0.2 \mathrm{~mm}$ layer of beeswax, the plates were closed and sealed to prevent 
Table 2. Mean Value (in $\mu \mathrm{g} \mathrm{kg}^{-1}$ ), Standard Deviation (SD, in $\mu \mathrm{g} \mathrm{kg}^{-1}$ ), and Coefficient of Variation (V.C., in \%) for the Determination of Sulfonamides in Honey $(n=6)$ at 2 and $4 \mu \mathrm{g} \mathrm{kg}^{-1}$ and for the Analysis of Sulfamethazine in Beeswax $(n=4)$ at 25 and $100 \mu \mathrm{g} \mathrm{kg}^{-1}$

honey

\begin{tabular}{|c|c|c|c|c|c|c|}
\hline \multirow[b]{2}{*}{ compound } & \multicolumn{3}{|c|}{ honey spiked at $2 \mu \mathrm{g} \mathrm{kg}^{-1}$} & \multicolumn{3}{|c|}{ honey spiked at $4 \mu \mathrm{g} \mathrm{kg}^{-1}$} \\
\hline & mean $\left(\mu \mathrm{g} \mathrm{kg}^{-1}\right)$ & $\mathrm{SD}\left(\mu \mathrm{g} \mathrm{kg}^{-1}\right)$ & V.C. (\%) & mean $\left(\mu \mathrm{g} \mathrm{kg}^{-1}\right)$ & $\mathrm{SD}\left(\mu \mathrm{g} \mathrm{kg}^{-1}\right)$ & V.C. $(\%)$ \\
\hline sulfamethazine & 2.00 & 0.14 & 7.00 & 4.27 & 0.17 & 3.92 \\
\hline sulfapyridine & 2.09 & 0.08 & 3.85 & 4.11 & 0.19 & 4.64 \\
\hline sulfadiazine & 2.02 & 0.16 & 8.04 & 4.07 & 0.13 & 3.31 \\
\hline sulfamethoxazole & 2.08 & 0.07 & 3.43 & 4.10 & 0.24 & 5.88 \\
\hline sulfathiazole & 2.01 & 0.25 & 12.23 & 3.97 & 0.22 & 5.49 \\
\hline sulfamerazine & 2.07 & 0.09 & 4.47 & 4.24 & 0.11 & 2.48 \\
\hline sulfaquinoxaline & 2.00 & 0.14 & 7.00 & 4.10 & 0.12 & 3.00 \\
\hline
\end{tabular}

\begin{tabular}{|c|c|c|c|c|c|c|}
\hline \multirow[b]{3}{*}{ compound } & \multicolumn{5}{|c|}{ Beeswax } & \\
\hline & \multicolumn{3}{|c|}{ wax spiked at $25 \mu \mathrm{g} \mathrm{kg}^{-1}$} & \multicolumn{3}{|c|}{ wax spiked at $100 \mu \mathrm{g} \mathrm{kg}^{-1}$} \\
\hline & mean $\left(\mu \mathrm{g} \mathrm{kg}^{-1}\right)$ & $\mathrm{SD}\left(\mu \mathrm{g} \mathrm{kg}^{-1}\right)$ & V.C. $(\%)$ & mean $\left(\mu \mathrm{g} \mathrm{kg}^{-1}\right)$ & $\mathrm{SD}\left(\mu \mathrm{g} \mathrm{kg}^{-1}\right)$ & V.C. $(\%)$ \\
\hline sulfamethazine & 26.90 & 0.86 & 3.20 & 117.57 & 8.46 & 7.19 \\
\hline
\end{tabular}

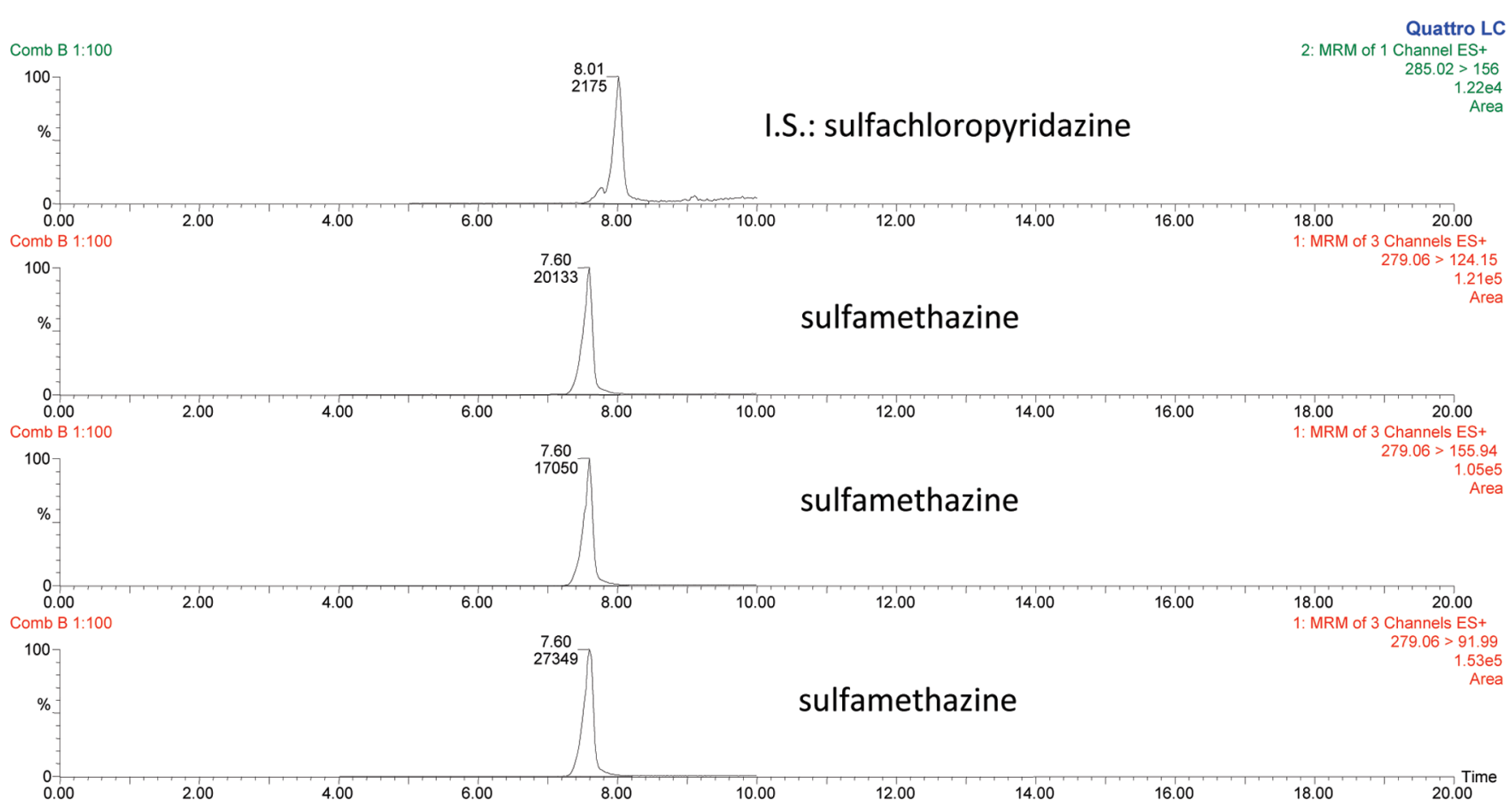

Figure 1. Chromatogram of the wax foundation of $\operatorname{comb} B, 100$ times diluted. $x$ axis, retention time in min; $y$ axis, abundance $(\%)$. Sulfachloropyridazine $=$ internal standard.

evaporation, and placed undisturbed in an incubator at $35{ }^{\circ} \mathrm{C}$ for 3 months. After 14 days, 1, 2, and 3 months, we opened four Petri dishes per sulfamethazine concentration. The syrup was discarded, and the beeswax was thoroughly washed with distilled water and dried with absorbent paper. The amount of sulfamethazine in the wax samples was determined by LC-MS/MS.

\section{RESULTS AND DISCUSSION}

For the 7 sulfa drugs tested in honey, the decision limit (CC $\alpha)$ was $\leq 2 \mu \mathrm{g} \mathrm{kg}^{-1}$, and depending on the type of sulfa drug, the detection capability $(\mathrm{CC} \beta)$ was in the range of $2.2-2.4 \mu \mathrm{g} \mathrm{kg}^{-1}$. The mean value, standard deviation, and coefficient of variation for six blank honey samples spiked at $2 \mu \mathrm{g} \mathrm{kg}^{-1}(\mathrm{CC} \alpha)$ and $4 \mu \mathrm{g} \mathrm{kg}^{-1}$ (2 CC $\alpha$ ) were determined. The results are given in Table 2 .
The decision limit $(\mathrm{CC} \alpha)$ for sulfamethazine and sulfadiazine in beeswax was $20 \mu \mathrm{g} \mathrm{kg}^{-1}$; the detection capability $(\mathrm{CC} \beta)$ was $25 \mu \mathrm{g} \mathrm{kg}^{-1}$. The mean value, standard deviation, and coefficient of variation for four blank beeswax samples spiked at 25 and $100 \mu \mathrm{g} \mathrm{kg}^{-1}$ were calculated. The results are summarized in Table 2.

All residue analyses were performed at ILVO. Since the spiking with sulfamethazine took place in heated liquid beeswax at $80^{\circ} \mathrm{C}$, leading to a certain degradation of the sulfa drug, parts of the spiked wax foundations were analyzed by LC-MS/MS to determine the concentration of sulfamethazine in the wax foundations. Figure 1 shows the chromatogram of the detection of sulfamethazine in the wax foundation of comb B, 100 times diluted. The wax foundations used in the migration experiment contained 590 (A), 3760 (B), and 73000 (C) $\mu \mathrm{g} \mathrm{kg}^{-1}$ sulfamethazine. This indicates 
Table 3. Concentration (in $\mu \mathrm{g} \mathrm{kg}^{-1}$ ) and Amount (in $\mu \mathrm{g}$ ) of Sulfamethazine in Honey and Percentage of Transfer (in \%) of Sulfamethazine from Beeswax at Different Sampling Dates $(n=1)^{a}$

\begin{tabular}{|c|c|c|c|c|c|c|c|c|c|}
\hline \multirow[b]{2}{*}{ time after start of experiment } & \multicolumn{3}{|c|}{ sulfamethazine concentration $\left(\mu \mathrm{g} \mathrm{kg}^{-1}\right)$ in honey } & \multicolumn{3}{|c|}{ sulfamethazine $(\mu \mathrm{g})$ in honey } & \multicolumn{3}{|c|}{ transfer $(\%)$ of sulfamethazine } \\
\hline & comb A & comb B & comb C & $\operatorname{comb} \mathrm{A}$ & comb B & comb C & comb A & comb B & comb C \\
\hline 1 month & $<2$ & 10 & 176 & $<4$ & 18 & 323 & $<10.4$ & 8.1 & 7.4 \\
\hline 2 months & 3 & 52 & 628 & 6 & 95 & 1152 & 15.6 & 42.3 & 26.3 \\
\hline 3 months & 2 & 58 & 704 & 4 & 106 & 1292 & 10.4 & 47.2 & 29.5 \\
\hline 4 months & 3 & 70 & 605 & 6 & 128 & 1110 & 15.6 & 56.9 & 25.3 \\
\hline
\end{tabular}

\begin{tabular}{llll}
\hline & hive A & hive B & hive C \\
\hline control comb & $<2$ & $<2$ & 4
\end{tabular}

${ }^{a}$ Combs A, B, and C with 590,3760 , and $73000 \mu \mathrm{g} \mathrm{kg}^{-1}$ sulfamethazine in the wax foundation, respectively. Percentages of transfer are based on $60 \mathrm{~g}$ of wax foundation and
$1.835 \mathrm{~kg}$ of honey per comb. Concentration (in $\mu \mathrm{g} \mathrm{kg}^{-1}$ ) of sulfamethazine in honey sampled from the control combs with residue-free beeswax from the beehives involved in the $1.835 \mathrm{~kg}$ of honey per
transfer experiment.

that 41,62 , and $27 \%$ of the initial spiked concentration, respectively, was lost due to heat degradation. The differences in degradation could possibly be explained by the longer time spent to mold the wax foundation spiked at $10 \mathrm{mg} \mathrm{kg}^{-1}$ sulfamethazine. The weight of a wax foundation was approximately $60 \mathrm{~g}$; hence, the total amount of sulfamethazine present in the wax foundations was 35,226 , and $4380 \mu \mathrm{g}$, respectively.

The results of the migration of sulfamethazine to the honey during storage of the honey in the combs are shown in Table 3 . The higher the concentration of sulfamethazine in the wax, the more residues were found in the honey. Migration of residues from the beeswax to the honey in combs $\mathrm{B}$ and $\mathrm{C}$ was still continuing in the first month of storage of the frames in the incubator. From the second sampling on, rather steady residue values were found in the honey. A level of $590 \mu \mathrm{g} \mathrm{kg}^{-1}$ sulfamethazine in the wax foundation resulted in measurable contaminations in honey, while $3760 \mu \mathrm{g} \mathrm{kg}^{-1}$ sulfamethazine in the wax foundation resulted in sulfamethazine contaminations in honey, surpassing the recommended concentration for the screening of $50 \mu \mathrm{g} \mathrm{kg}^{-1}$ as proposed by EU Community Reference Laboratory. The control honey samples from hives A and B were free of sulfa residues, while $4 \mu \mathrm{g} \mathrm{kg}^{-1}$ of sulfamethazine was found in the control sample from the third hive. The control honey results excluded external sources of contamination and indicated that the sulfamethazine in the honey samples fully originated from the spiked beeswax. Regarding the low contamination of $4 \mu \mathrm{g} \mathrm{kg}^{-1}$ of sulfamethazine in the comb of hive $\mathrm{C}$, it is known that bees always recuperate and move material. Therefore, it is possible that bees of that hive were transferring small quantities of contaminated honey to other honeycombs in the same super.

The sampling of honey by spooning was always performed at places where the comb was fully built out by the bees to the thickness of the wooden frame $(2.3 \mathrm{~cm})$ and filled with capped honey. A frame completely filled with honey contained approximately $1.84 \mathrm{~kg}$ of honey. At all sampling sites on the comb, the wax/honey ratio was consequently always $60 \mathrm{~g}: 1.84 \mathrm{~kg}$. When these conditions ( $60 \mathrm{~g}$ of wax foundation and $1.84 \mathrm{~kg}$ of honey) were taken into account, the maximum amount of sulfamethazine that migrated from the three spiked wax foundations to the honey was $15.6,56.9$, and $29.5 \%$. These figures show that sulfamethazine is not so lipophilic and is quite easily released from the wax to migrate to the honey in the combs. In our experiment, we used sulfamethazine since this sulfonamide was the most commonly identified in Flemish honey. The probability that other sulfonamides also transfer from contaminated beeswax to honey is very high. The percentage of transfer is dependent on the lipophilicity of the substance. The octanol/water partition coefficient for some sulfa drugs was calculated with specialized software. The $\log P$
Table 4. $\log P$ Values for Some Sulfa Drugs

\begin{tabular}{llr}
\hline \multicolumn{1}{c}{ compound } & CAS number & \multicolumn{1}{c}{$\log P$} \\
\hline sulfamethazine & $57-68-1$ & $0.803 \pm 0.259$ \\
sulfapyridine & $144-83-2$ & $0.034 \pm 0.318$ \\
sulfadiazine & $68-35-9$ & $-0.117 \pm 0.255$ \\
sulfamethoxazole & $723-46-6$ & $0.887 \pm 0.419$ \\
sulfathiazole & $72-14-0$ & $0.047 \pm 0.396$ \\
sulfamerazine & $127-79-7$ & $0.343 \pm 0.257$ \\
sulfaquinoxaline & $59-40-5$ & $1.305 \pm 0.385$ \\
sulfachloropyridazine & $80-32-0$ & $1.018 \pm 0.622$ \\
\hline
\end{tabular}

values or the logarithm of the ratio of the concentrations of the un-ionized sulfa drugs in the solvents water and octanol are shown in Table 4. Chemicals with low $\log P$ values (e.g., less than 1) may be considered relatively hydrophilic; conversely, chemicals with high $\log P$ values (e.g., greater than 4$)$ are very hydrophobic. The $\log P$ value for sulfamethazine (0.803, relatively hydrophilic) explains the high percentages of transfer of sulfamethazine from beeswax to honey. In comparison to sulfamethazine, sulfamethoxazole, sulfaquinoxaline, and sulfachloropyridazine are somewhat more lipophilic, while sulfapyridine, sulfadiazine, sulfathiazole, and sulfamerazine are more hydrophilic.

The transfer results of the in vivo experiment indicate that the purchase and the use of contaminated wax foundations by the beekeeper can lead to low-level sulfonamide contaminations in honey. Beekeepers can be advised to recycle their own beeswax for the fabrication of the wax foundations or to ask for a certificate when buying wax foundations from wax transforming factories that mostly use wax from unknown origins. Under practical conditions, wax is recycled from different types of comb material, namely, brood combs, honeycombs, and cappings. At wax transforming factories, a single lot of highly contaminated wax could cause a high residual concentration in all resulting foundations (45). The use of a synthetic foundation wax such as Syncera (46) could also be an effective alternative. Fully drawn plastic foundations, with the hexagonal worker cells embedded in the plastic, are also available. This study also indicates that in case authorities are considering a zero-tolerance for antimicrobial residues in honey, beekeepers could lose their honey production just by using wax foundations bought in the market. The use of action limits could be an answer to this problem.

However, not all cases of low-level sulfonamide contamination in Flemish honey can be claimed to be caused by the use of sulfacontaminated wax foundations. Other sources of sulfonamide contamination could be the robbery by bees of contaminated honey from hives of other apiaries (47), the feeding of sulfonamidecontaminated honey to bee colonies by the beekeeper, and the mixing of privately produced honey with external honey of 
Table 5. Concentration (in $\mu \mathrm{g} \mathrm{kg}^{-1}$ ) and Amount (in $\mu \mathrm{g}$ ) of Sulfamethazine in $30 \mathrm{~mL}$ of Beeswax and Percentage of Transfer (in \%) of Sulfamethazine from Syrup to Blank Beeswax after 14 days, 1, 2, and 3 Months of Contact with $50 \mathrm{~mL}$ of Medicated Syrup Solution $(n=1)^{a}$

\begin{tabular}{|c|c|c|c|c|c|c|c|c|c|}
\hline \multirow[b]{2}{*}{ incubation } & \multicolumn{3}{|c|}{ sulfamethazine concentration $\left(\mu \mathrm{g} \mathrm{kg}^{-1}\right)$ in beeswax } & \multicolumn{3}{|c|}{ sulfamethazine $(\mu \mathrm{g})$ in beeswax } & \multicolumn{3}{|c|}{ transfer $(\%)$ of sulfamethazine } \\
\hline & syrup $A$ & syrup B & syrup C & syrup $A$ & syrup B & syrup C & syrup $A$ & syrup $B$ & syrup $\mathrm{C}$ \\
\hline 14 days & 109 & 500 & 2000 & 3 & 15 & 58 & 0.2 & 0.2 & 0.2 \\
\hline 1 month & 115 & 2000 & 5000 & 3 & 58 & 145 & 0.2 & 0.8 & 0.4 \\
\hline 2 months & 96 & 8000 & 6000 & 3 & 232 & 174 & 0.2 & 3.1 & 0.5 \\
\hline 3 months & 101 & 7000 & 24000 & 3 & 203 & 696 & 0.2 & 2.7 & 1.9 \\
\hline
\end{tabular}

a Syrups A, B, and C were spiked with 30000,150000 , and $750000 \mu \mathrm{g} \mathrm{L}^{-1}$ sulfamethazine, respectively.

dubious quality. There is also the possibility that the source of contamination with sulfonamides is related to agricultural practices, e.g., bees can collect sulfa-medicated drinking water from poultry farms, rabbit cages, or race-pigeon lofts. The manure of animals (pigs/cows) treated with sulfonamides or sulfa-containing surface water could also be the vector (48). In the case of the low contamination of Flemish honey, the link to agriculture cannot be completely ruled out. However, it is considered to be rather unlikely for some sulfa drugs without registration in Belgium, e.g., sulfamethazine. Contamination of honey with residues of sulfanilamide could also be caused by the collection by bees of nectar from meadows treated with the herbicide asulam. Such honey is contaminated not only by asulam but also by its degradation product sulfanilamide (35).

Beeswax and propolis are most likely to be contaminated with synthetic acaricides since varroacides have to be used for longterm Varroa destructor control. Synthetic acaricides such as bromopropylate, coumaphos, fluvalinate, and flumethrin are mostly fat-soluble and persist in wax. After acaricide treatments, they accumulate in wax and contaminate honey to a much lesser extent $(49,50)$. The rate of transfer of acaricides to honey is directly related to their lipophilicity. Recycling of wax by melting of combs has no degradation effect on acaricide concentration (50). The use of CheckMite+ (coumaphos) for the chemical treatment of the small hive beetle (Aethina tumida) even results in higher residue levels in wax and honey than those found after the use of coumaphos against Varroa (51). para-Dichlorobenzene and naphthalene are sometimes used for wax moth (Galleria mellonella and Achroia grisella) control. These practices result in residues of these compounds in the wax and honey (41). But the experiment described here is the first to report that contaminated beeswax could be the vector of honey contamination with antimicrobial residues. There is a high persistence of sulfonamide residues in honey and in beeswax inside the hive. In 1950, a patent was given to the invention of bee comb foundation with sulfathiazole incorporated in the beeswax to protect the hives against American foulbrood (52). Sulfa drugs are known to remain effective at a hive temperature of $34{ }^{\circ} \mathrm{C}$ for at least 3 years (53). No information was available on the persistence of sulfa drugs in recycled beeswax. The persistence depends on the lipophilicity of the substances and their stability at temperatures above the melting point of beeswax. In our experiment, beeswax was melted on a hot plate at $80^{\circ} \mathrm{C}$, and a maximum loss of $62 \%$ was stated. In wax transforming factories where large amounts of beeswax are melted, the heating time will be much longer than the time applied for the molding of the three spiked wax foundations in our experiment. However, there are serious indications that remelting of wax is not eliminating all sulfa residues.

To check as to what extent the beeswax can be contaminated by the application of sulfa drugs, we investigated the transfer from medicated syrup solution to blank beeswax in an in vitro experiment. The migration of sulfamethazine to beeswax from 3 syrup solutions with a different sulfamethazine concentration was followed for 3 months. The results of the sulfamethazine concentrations measured by LC-MS/MS in the beeswax after 14 days, 1, 2, and 3 months of contact with $50 \mathrm{~mL}$ of medicated sucrose syrup are summarized in Table 5. A concentration of 30 $\mathrm{mg} \mathrm{kg}-1$ sulfamethazine in the syrup resulted in a maximum sulfamethazine concentration of $115 \mu \mathrm{g} \mathrm{kg}^{-1}$ in the beeswax, and a plateau was reached after 2 weeks of contact. Concentrations of 150 and $750 \mathrm{mg} \mathrm{kg}^{-1}$ sulfamethazine in the syrup resulted in maximum 8000 and $24000 \mu \mathrm{g} \mathrm{kg}^{-1}$ sulfamethazine in the beeswax, respectively. The maximum level was reached after 2 and 3 months of contact, respectively. The total amount of sulfamethazine in the syrup on top of the wax was $1.5 \mathrm{mg}$ (syrup A), $7.5 \mathrm{mg}$ (syrup B), and $37.5 \mathrm{mg}$ (syrup C), respectively. The maximal amount of sulfamethazine transferred was 3, 232, and $696 \mu \mathrm{g}$ or $0.2,3.1$, and $1.9 \%$, respectively. There is no direct explanation for the rather big differences in transfer percentages. As could be expected for the rather hydrophilic sulfamethazine $(\log P=$ $0.803)$, these data indicate that beeswax has a certain ability to retain sulfamethazine. On the basis of the $\log P$ values mentioned in Table 4, the same could be supposed for other sulfa drugs.

In Europe, the provision of winter feed is normally given by the beekeepers before the end of September. This feed is stored by the bees in the combs and will be consumed during wintertime and in spring. The contact time is in practice as long as or even longer than the three months applied in the experiment. Mutinelli (54) mentions an application of sulfathiazole in USA against European foulbrood. During three gorging treatments at 4 to 5 day intervals, they administered medicated syrup containing $265 \mathrm{mg} \mathrm{L}^{-1}$ sulfathiazole (equivalent to $1 \mathrm{~g}$ of sulfathiazole per gallon). This is in the range of concentrations applied in the experiment. In reality, the ratio of volume of stored syrup in capped cells in relation to the weight of beeswax is much higher than the ratio of $50 \mathrm{~mL}: 29 \mathrm{~g}$ in the experiment. Therefore, in reality higher transfer percentages could be expected.

This experiment indicates that after application of sulfamethazine, high concentrations of sulfamethazine residues can be expected in the wax. This is likely to be the case for other sulfa drugs as well. However, the monitoring data reveal rather low sulfa concentrations (62 and $325 \mu \mathrm{g} \mathrm{kg}^{-1}$ of sulfadiazine in bulk beeswax and only $14 \mu \mathrm{g} \mathrm{kg}^{-1}$ of sulfamethazine in wax from a honeycomb of a hive with the production of sulfa-contaminated honey). A possible explanation could be that the contaminated beeswax is largely diluted by pure beeswax coming from different apiaries. Concerning the wax of the individual honeycomb, there is no certainty that this comb was already present in the hive during sulfa application in the winter feed of the previous year. It is possible that the comb sampled in summer originated from a wax foundation given in spring.

Conclusions. The presence of residues of sulfonamides in beeswax was confirmed by a newly developed LC-MS/MS method. A migration experiment followed the transfer of sulfamethazine from beeswax to honey. The higher the concentration of sulfamethazine doped in the wax, the higher was the concentration of sulfamethazine found in the honey. The maximum 
transfer was $15.6,56.9$, and $29.5 \%$, respectively, of the initial amount spiked in the wax foundation.

A second in vitro experiment determined the percentage of sulfamethazine migrating from medicated winter feed to beeswax in relation to the concentration in the syrup and the contact time. The maximum transfer of sulfamethazine from medicated sucrose syrup to beeswax was $3.1 \%$. The higher the concentration of sulfamethazine doped in the syrup, the longer it takes to get the highest percentage of transfer.

The results of both experiments indicate that after the use of sulfonamides in the hive, a pool of residues remains in the wax of the combs. Residues remaining in the beeswax can contaminate the honey during the next honey season. Therefore, the harvest and destruction of the first honey production are not sufficient measures to guarantee residue-free honey in later productions. Especially in the countries without tolerance levels for sulfa drugs in honey, low concentrations of sulfonamides in honey could have serious implications. Our findings also imply that veterinarians prescribing sulfonamides in apiculture based on the cascade system may find it difficult to indicate withdrawal periods. These consequences should also be kept in mind should the European Commission choose to fix MRLs for anti-infectious agents in honey. The results also indicate serious implications regarding the recycling of beeswax.

\section{ACKNOWLEDGMENT}

We appreciate the excellent practical work performed by Petra De Neve, Kurt Hullebusch, Katleen Vander Straeten, and Patricia Van Herreweghe (ILVO-T\&V) and language correction of the manuscript by Miriam Levenson (ILVO) .

\section{LITERATURE CITED}

(1) Haseman, L.; Childers, L. F. Controlling American foulbrood with sulfa drugs. Univ. Missouri Agric. Exp. Sta. Bull. 1944, 482, 3-16.

(2) Eckert, J. E. Use of sulfa drugs in the treatment of American foulbrood disease of honeybees. J. Econ. Entomol. 1947, 40, 41-44.

(3) Reinhardt, J. F. The sulfathiazole cure of American foulbrood: an explanatory theory. J. Econ. Entomol. 1947, 40, 45-48.

(4) Johnson, J. P. Sulfa drugs for American foul brood of honeybees: Third Report. J. Econ. Entomol. 1948, 41 (2), 314-318.

(5) Katznelson, H.; Gooderman, C. B. Sulfathiazole in relation to American foulbrood. Sci. Agric. 1949, 32, 180-184.

(6) Katznelson, H. The influence of antibiotics and sulpha drugs on Bacillus larvae, cause of American foulbrood of the honeybee, in vitro and in vivo. J. Bacteriol. 1950, 59, 471-479.

(7) Shimanuki, H.; Knox, D. A. Susceptibility of Bacillus larvae to Terramycin. Am. Bee J. 1994, 134, 125-126.

(8) Fischer, M. W.; Jeffrey, D. P. Evidence from small-subunit ribosomal RNA sequences for a fungal origin of Microsporidia. Mol. Phylogenet. Evol. 2005, 36, 606-622.

(9) Higes, M.; Martin, R.; Meana, A. Nosema ceranae, a new microsporidian parasite in honeybees in Europe. J. Invertebr. Pathol. 2006, $92(2), 93-95$.

(10) Katznelson, H.; Jamieson, C. A. Control of Nosema disease of honeybee with fumagillin. Science 1952, 115, 70-71.

(11) Piro, R.; Mutinelli, F. The EU legislation for honey residue control. Apiacta 2003, 38, 226-234.

(12) Lourdes, J. Evaluación de un méthodo de análisis de residuos de sulfamidas, en miel de abejas (Apis mellifera L.), a través de cromatografía líquida de alta precisión (HPLC), en fase reversa. Thesis, Universidad Austral de Chile, Facultad de Ciencias Agrarias, Escuela de Ingeniería en Alimentos: Valdivia, Chile, 2002.

(13) Manual de Patología Apícola. Secretaría de Agricultura, Ganadería, Desarrollo Rural, Pesca y Alimùentation. http://www.mundoapicola.com/PDF/patologia/manualpatologiaapicolamejico.pdf, 2010.

(14) Liu, L. X.; Weller, P. F. Antiparasitic drugs. N. Eng. J. Med. 1996, $334(18), 1178-1182$.
(15) Didier, E. S. Microsporidiosis. Clin. Infect. Dis. 1998, 27, 1-8.

(16) Conteas, C. N.; Berlin, O. G. W.; Ash, L. R.; Pruthi, J. S. Therapy for human gastrointestinal microsporidiosis. Am. J. Trop. Med. Hyg. 2000, 63 (3), 121-127.

(17) Sweetman, S. C., Ed.;Martindale: The Complete Drug Reference, 34th ed.; Royal Pharmaceutical Society of Great Britain, Pharmaceutical Press: London, U.K., 2005.

(18) Council Regulation (EEC) No 2377/90 of 26 June 1990 laying down a community procedure for the establishment of maximum residue limits of veterinary medicinal products in foodstuffs of animal origin. Off. J. Eur. Commun. 1990, L224, 1-8.

(19) Council Regulation (EC) No 470/2009 of the European Parliament and of the Council of 6 May 2009 laying down Community procedures for the establishment of residue limits of pharmacologically active substances in foodstuffs of animal origin, repealing Council Regulation (EEC) No 2377/90 and amending Directive 2001/82/EC of the European Parliament and of the Council and Regulation (EC) No 726/2004 of the European Parliament and of the Council laying down a Community procedure for the establishment of maximum residue limits of veterinary medicinal products in foodstuffs of animal origin. Off. J. Eur. Commun. 2009, L152, $11-22$.

(20) Council Regulation (EU) No 37/2010 of 22 December 2009 on pharmacologically active substances and their classification regarding maximum residue limits in foodstuffs of animal origin. Off. $J$. Eur. Union 2010, L15, 1-72.

(21) Advies 2001/11: Betreft: Residuen van antibiotica en sulfonamiden in honing (dossier Sc Com 2001/11). Wetenschappelijk Comité van FAVV. http://www.favv.be/home/com-sci/avis01_nl.asp, 2001.

(22) Annual Report on Surveillance for Veterinary Residues in the UK, 2003. http://www.vet-residues-committee.gov.uk/reports/nonstat2003. pdf, 2003.

(23) Martel, A. C.; Zeggane, S. HPLC determination of sulfathiazole in French honeys. J. Liq. Chromatogr. Relat. Technol. 2003, 26, $953-$ 961.

(24) CRL Guidance Paper (7 December 2007). CRLs view on state of the art analytical methods for national residue control plans. Community Reference Laboratories (CRLs) for residues according to Council Directive 96/23/EC. 2007; pp 1-8.

(25) Directive 2001/82/EC of the European Parliament and of the Council of 6 November 2001 on the Community code relating to veterinary medicinal products. Off. J. Eur. Comm. 2001, L311, 1-66.

(26) Directive 2004/28/EC of the European Parliament and of the Council of 31 March 2004 amending Directive 2001/82/EC on the Community code relating to veterinary medicinal products. Off. $J$. Eur. Commun. 2004, L136, 58-84.

(27) Note of the Commission Dated 24 July 2007 to the Members and Observers of the Veterinary Pharmaceutical Committee (GG). In Summary Record of the Standing Committee on the Food Chain and Animal Health Held on 18 September 2007 in Brussels. http://ec.europa. eu/food/committees/regulatory/scfcah/biosafety/sum_18092007_en. pdf, 2007.

(28) Reybroeck, W. Residues of antibiotics and sulphonamides in honey on the Belgian market. Apiacta 2003, 38, 23-30.

(29) Reybroeck, W.; Daeseleire, E.; Ooghe, S.; Jacobs, F. Sulpha Drugs in Honey and Other Bee Products. In Proceedings of the 2nd Apimondia Symposium on the Prevention of Residues in Honey; Apimondia: Celle, Germany, 2004.

(30) Reybroeck, W.; Ooghe, S.; Jacobs, F. 10 Jaar honinganalyses in Vlaanderen (1998-2007). Themanummer HONING. Maandblad van de Vlaamse Imkersbond, Augustus 2008; 2008; pp 4-16.

(31) Heering, W.; Usleber, E.; Dietrich, R.; Märtlbauer, E. Immunochemical screening for antimicrobial drug residues in commercial honey. Analyst 1998, 123 (12), 2759-2762.

(32) Morlot, M.; Beaune, P. An experience with Charm II system. Apiacta 2003, 38, 15-20.

(33) Posyniak, A.; Zmudzki, J.; Niedzielska, J.; Sniegocki, T.; Grzebalska, A. Sulfonamide residues in honey. Control and development of analytical procedure. Apiacta 2003, 38, 249-256.

(34) Wallner, K. Sulfonamide-residues in German honey: The actual situation. Apidologie 2003, 34, 485. 
(35) Kaufmann, A.; Känzig, A. Contamination of honey by the herbicide asulam and its antibacterial active metabolite sulphanilamide. Food Addit. Contam. 2004, 21 (6), 564-571.

(36) Sheridan, R.; Policastro, B.; Thomas, S.; Rice, D. Analysis and occurrence of 14 sulfonamide antibacterials and chloramphenicol in honey by Solid-Phase Extraction followed by LC/MS/MS analysis. J. Agric. Food Chem. 2008, 56 (10), 3509-3516.

(37) RASFF Portal: online searchable database. http://ec.europa.eu/ food/food/rapidalert/rasff_portal_database_en.htm, 2010.

(38) Commission Decision (EC) No 2002/657 of 12 August 2002 implementing Council Directive 96/23/EC concerning the performance of analytical methods and the interpretation of results. Off. J. Eur. Comm. 2002, L221, 8-36.

(39) Bogdanov, S. Quality and standards of pollen and beeswax. Apiacta 2004, 38, 334-341.

(40) Bogdanov, S.; Ryll, G.; Roth, H. Pesticide residues in honey and beeswax produced in Switzerland. Apidologie 2003, 34, 484-485.

(41) Bogdanov, S. Contamination of bee products. Apidologie 2006, 37, $1-18$.

(42) Reybroeck, W.; Daeseleire, E.; Jacobs, F. Residue Formation of Sulfonamides in Honey by Migration from Contaminated Beeswax. In Final Program \& Abstracts of the 40th Apimondia International Apicultural Congress; Melbourne, Australia, 2007; p 206.

(43) Reybroeck, W.; Daeseleire, E.; Jacobs, F. Can Sulfa-Contaminated Beeswax Lead to Residues in Honey? In EuroResidue VI: Conference on Residues of Veterinary Drugs in Food; Van Ginkel, L. A., Bergwerff, A. A., Eds.; Egmont aan Zee, the Netherlands, 2008; pp 43-45.

(44) Maudens, K.; Zhang, G.-F.; Lambert, W. Quantitative analysis of twelve sulphonamides in honey after acidic hydrolysis by high-performance liquid chromatography with post-column derivatization and fluorescence detection. J. Chromatogr. 2004, 1047 (1), 85-92.
(45) Lodesani, M.; Costa, C.; Bigliardi, M.; Colombo, R. Acaricide residues in bee wax and organic beekeeping. Apiacta 2003, 38, 31-33.

(46) Jacobs, F. J.; Remon, J. P. The Discovery and Practical Use of a Substitute for Bee-Wax. In Abstracts of Apimondia International Apicultural Congress; Durban, South Africa, 2001.

(47) Seiler, K.; Kaufmann, A. Kontamination von Honig mit Sulfathiazol durch Raüberei unter Bienen. Mitt. Geb. Lebensmittelunters. Hyg. 2002, 93, 437-446.

(48) Richter, D.; Bogdanov, S.; Edder, P. Antibiotikarückstände-von der Gülle in der Honig? Schweiz. Bienen-Ztg. 2005, 128 (2), 23-25.

(49) Wallner, K. Varroacides and their residues in bee products. Apidologie 1999, 30, 235-248.

(50) Bogdanov, S.; Kilchenmann, V.; Imdorf, A. Acaricide residues in some bee products. J. Apic. Res. 1998, No. 37, 57-67.

(51) Nasr, M. E.; Wallner, K. Miticides residues in honey and wax in North America. Am. Bee J. 2003, 143, 322.

(52) Small, A. V. Beecomb Foundation. Application November 18, 1947. Serial No. 786,791. U.S. Patent 2,494,9047, January 17, 1950.

(53) Katznelson, H.; Jamieson, C. A. Note on current studies on the chemotherapy of American foulbrood of the honeybee and on the stability of sulpha drugs in honey. Sci. Agric. 1954, 34, 120.

(54) Mutinelli, F. Practical application of antibacterial drugs for the control of honey bee diseases. Apiacta 2003, 38, 149-155.

Received for review February 8, 2010. Revised manuscript received May 5, 2010. Accepted May 12, 2010. Parts of the results of this article were presented at the 40th Apimondia International Apicultural Congress (42) and at EuroResidue VI, Conference on Residues of Veterinary Drugs in Food (43). 